\title{
Jurist-Diction
}

Volume 4 No. 2, Maret 202

\section{Pemenuhan Hak Masyarakat Miskin Terhadap Perumahan dan Permukiman yang Layak di Perkotaan Indonesia: Studi Perbandingan Singapura dan Australia}

\author{
Brillian Aditya Prawira Arafat dan Vicko Taniady \\ adityabrillian2@gmail.com \\ Universitas Jember
}

\begin{abstract}
How to cite:
Brillian Aditya Prawira Arafat dan Vicko Taniady,

'Pemenuhan Hak Masyarakat Miskin Terhadap Perumahan dan Permukiman yang Layak di Perkotaan Indonesia: Studi Perbandingan Singapura dan Australia' (2021) Vol. 4 No. 2 Jurist-Diction.
\end{abstract}

\section{Histori artikel:}

Submit 4 Januari 2021;

Diterima 11 Februari 2021;

Diterbitkan 1 Maret 2021.

DOI:

10.20473/jd.v4i2.25753

p-ISSN: $2721-8392$

e-ISSN: $2655-8297$

\begin{abstract}
This research will examine government regulation and implementation to meet the poor's housing needs in urban Indonesia. In Indonesia, the increase in the poor has resulted in the number of slum settlements increasing sharply. As a comparison, the authors compare the fulfilment of the poor's rights to adequate housing in Singapore and Australia, which can suppress slum settlements. The research method used is normative law using literature study with a comparative law approach between Indonesia, Singapore and Australia. This study indicates that the legal regulations governing decent housing and settlements have been contained in various national regulations. However, it is complicated in its implementation, especially due to the government's inconsistency in fulfilling human rights for the poor, especially the fulfilment of adequate housing in urban areas. There needs to be an urgency to fulfil the rights of the poor to decent housing and settlements by reflecting on Singapore and Australia policies. Keywords: Human Rights; Housing and Decent Settlements; Poor Society.
\end{abstract}

\section{Abstrak}

Penelitian ini akan mengkaji regulasi dan implementasi pemerintah dalam upaya pemenuhan kebutuhan pemukiman bagi masyarakat miskin di perkotaan Indonesia. Di Indonesia peningkatan masyarakat miskin mengakibatkan jumlah permukiman kumuh meningkat dengan tajam. Sebagai pembanding, penulis membandingkan pemenuhan hak masyarakat miskin terhadap pemukiman layak di negara Singapura dan Australia yang mampu menekan pemukiman kumuh. Metode penelitian yang digunakan adalah hukum normatif yang menggunakan studi pustaka dengan pendekatan comparative law antara negara Indonesia, Singapura dan Australia. Hasil penelitian ini menunjukkan bahwa regulasi hukum yang mengatur tentang perumahan dan permukiman yang layak telah tertuang dalam berbagai peraturan nasional. Namun, dalam wujud pengimplementasiannya terasa sangat sulit terutama akibat dari inkonsistensi pemerintah dalam pemenuhan HAM bagi masyarakat miskin terkhusus pemenuhan permukiman yang layak di perkotaan. Sehingga perlu adanya urgensi untuk memenuhi hak masyarakat miskin terhadap perumahan dan permukiman yang layak dengan mengaca kebijakan Singapura dan Australia.

Kata Kunci: HAM; Perumahan dan Permukiman Layak; Masyarakat Miskin.

Copyright (C) 2021 Universitas Airlangga 


\section{Pendahuluan}

Pemenuhan hak asasi manusia untuk mengatasi permasalahan penduduk miskin dapat dimulai dari pemenuhan hak atas perumahan dan permukiman yang layak. ${ }^{1}$ Pemenuhan tersebut menjadi permasalahan yang sangat krusial bagi masyarakat miskin yang berada di perkotaan Indonesia. Sehingga tak jarang pula, masyarakat miskin di perkotaan hidup di perumahan yang tidak layak huni, gedung kosong, di bawah jembatan tol, pinggiran rel kereta api dan beberapa wilayah yang tidak layak untuk dihuni. ${ }^{2}$ Di Indonesia sendiri, peningkatan jumlah perumahan dan permukiman yang tidak layak semakin meningkat yang diiringi dengan meningkatnya jumlah angka kemiskinan. Pada tahun 2018, persentase rumah kumuh di perkotaan Indonesia mencapai 7,42\%, angka tersebut naik secara signifikan pada tahun 2019 dengan menyentuh angka 13,86\%. ${ }^{3}$

Isu hukum tersebut sangat urgensi untuk dibahas, yang dimana pemenuhan hak tersebut telah tercantum dalam pasal $28 \mathrm{H}$ ayat 1 yang mengamanatkan bahwa tempat tinggal yang baik dan sehat merupakan hak semua orang. Pada pasal 40 Undang-Undang Nomor 39 Tahun 1999 tentang Hak Asasi Manusia juga sudah mengungkapkan secara tegas bahwa setiap orang berhak untuk bertempat tinggal serta berkehidupan yang layak. Pengaturan lebih lanjut juga diatur dalam UndangUndang Nomor 1 Tahun 2011 tentang Perumahan dan Kawasan Permukiman (PKP) yang menyatakan bahwa negara memiliki tanggung jawab untuk menyelenggarakan perumahan dan permukiman yang layak dan terjangkau serta berkelanjutan diseluruh wilayah Indonesia. Berdasarkan peraturan Undang-Undang Nomor 1 Tahun 2011 tentang PKP dan Peraturan Pemerintah Nomor 14 Tahun 2016 tentang Penyelenggaraan Permukiman dan Kawasan Permukiman menjelaskan bahwa

1 I Dewa Gede Agung Diasana Putra dan Anak Agung Gde Yana, "Pemenuhan Atas Perumahan Salah Satu Upaya Penanggulangan Kemiskinan” (2007) 5 Jurnal Pemukiman Natah.[105].

${ }^{2}$ Valeria Ulu dan Nihayatus Sholichah, "Evaluasi Program Rehabilitasi Sosial Daerah Kumuh Terhadap PeningkaTan Kualitas Hidup Warga di Kelurahan Ngagelrejo, Kecamatan Wonokromo Kota Surabaya" (2020) 4 Jurnal Asketik: Agama dan Perubahan Sosial 85.[96-97].

${ }^{3}$ Badan Pusat Statistik, "Persentase Rumah Tangga Kumuh Perkotaan (40\% Ke Bawah), Menurut Provinsi (Persen), 2017-2019” (2019) < https://www.bps.go.id/indicator/23/1561/1/persentase-rumah-tangga-kumuh-perkotaan-40-ke-bawah-menurut-provinsi.html $>$ diakses 25 Oktober 2020. 
pembangunan perumahan harus meliputi ketersediaan prasarana, sarana dan utilitas umum. Di sisi lain, menurut Kementrian Pekerjaan Umum dan Perumahan Rakyat (PUPR) mengungkapkan empat kriteria rumah layak huni yang meliputi struktur konstruksi yang kuat, luas bangunan, sanitasi yang baik serta ketersediaan jaringan air bersih. ${ }^{4}$

Sebagai pembanding, Penulis membandingkan pemenuhan hak permukiman dan perumahan yang layak bagi masyarakat miskin di Singapura dan Australia. Adapun latar belakang pemilihan kedua negara tersebut adalah: Pertama, Singapura merupakan salah satu negara yang dalunya menjadi negara yang memiliki kawasan kumuh terparah di dunia. ${ }^{5}$ Selanjutnya, Singapura melakukan perubahan yang sangat signifikan dengan mengeluarkan kebijakan Housing Development Board yang menghapus rumah kumuh di Singapura. ${ }^{6}$ Kedua, Australia merupakan negara yang sama dengan Indonesia, yang sedang melakukan kebijakan sebagai upaya pemenuhan hak masyarakat miskin terhadap perumahan yang layak. Australia mengeluarkan program Australians for Affordable Housing. ${ }^{7}$ Program tersebut berhasil mempengaruhi harga pasar perumahan yang lebih terjangkau.

Mengingat penelitian yang berkaitan dengan pemenuhan permukiman yang layak bagi masyarakat miskin di perkotaan telah dilakukan beberapa kali sebelumnya, seperti: 1) Penelitian yang dilakukan oleh Caecilia Waha dan Jemmy Sondakh yang berjudul Pemenuhan Hak atas Perumahan yang Layak Bagi Masyarakat Miskin

${ }^{4}$ BAGIAN HUKUM DAN KOMUNIKASI PUBLIK DITJEN PENYEDIAAN PERUMAHAN KEMENTERIAN PUPR, "Kementerian PUPR Tetapkan 4 Kriteria Rumah Layak Huni” (2020) <https://perumahan.pu.go.id/berita/view/212/kementerian-pupr-tetapkan-4-kriteriarumah-layak-huni $>$ diakses 25 Oktober 2020.

5 detikNews, "Mereka yang Ubah Daerah Kumuh di Berbagai Negara Jadi Permukiman Layak" (2019) <https://news.detik.com/bbc-world/d-4426586/mereka-yang-ubah-daerah-kumuhdi-berbagai-negara-jadi-permukiman-layak> diakses 26 Oktober 2020.

6 Tony Tan Keng Joo dan Tai Chee Wong, "Public housing in singapore: A sustainable housing form and development" [2008] Springer 135.[135-136].

${ }^{7}$ Lou Wilson and others, "National housing policy in Australia: Are new initiatives in affordable housing sustainable?” (2010) 5 International Journal of Interdisciplinary Social Sciences 129.[130-132]. 
di Perkotaan (Suatu Kajian dalam Perspektif Hak Asasi Manusia). ${ }^{8}$ Penelitian ini mengkaji sejauh mana tanggung jawab negara dalam pemenuhan perumahan bagi masyarakat miskin di Indonesia. Adapun hasil penelitian ini mengemukakan bahwa pemenuhan hak terhadap perumahan yang layak masih belum dijalankan secara konsisten di Indonesia terkhusus di Kota Manado dan Makassar. 2) Penelitian yang dilakukan oleh I Dewa Gede Agung Diasana Putra dan Anak Agung Gde Yana dengan judul penelitian Pemenuhan Atas Perumahan Salah Satu Upaya Penanggulangan Kemiskinan. ${ }^{9}$ Penelitian ini dilakukan untuk mengetahui strategi dalam upaya pemenuhan perumahan yang layak bagi masyarakat miskin sebagai penanggulangan kemiskinan. Hasil penelitian ini menunjukkan perlu adanya sistem standarisasi dan sistem koordinasi sebagai upaya penyediaan rumah murah dan layak huni bagi masyarakat miskin di Indonesia. 3) Penelitian yang dilakukan oleh Firdaus yang berjudul Pemenuhan Hak atas Perumahan yang Layak bagi Masyarakat Miskin Kota dalam Perspektif HAM. ${ }^{10}$ Penelitian ini bertujuan untuk mengetahui serta memahami tanggung jawab negara sebagai pemenuhan permukiman yang layak bagi masyarakat miskin di Kota Surabaya dan Makassar. Adapun hasil penelitian ini mengungkapkan kendala-kendala yang dihadapi dalam upaya pemenuhan hak tersebut yang meliputi mahalnya harga lahan di perkotaan, semakin sedikitnya lahan yang tersedia dan sebagainya.

Berdasarkan penelitian yang dilakukan sebelumnya, penelitian ini memiliki kesamaan tema mengenai pemenuhan hak masyarakat miskin terhadap perumahan yang layak. Namun, penelitian ini lebih menekankan pada pemenuhan hak terhadap

\footnotetext{
8 Caecilia Waha dan Sondakh Jemmy, "Pemenuhan Hak Atas Perumahan Yang Layak Bagi Masyarakat Miskin di Perkotaan (Suatu Kajian Dalam Perspektif Hak Asasi Manusia)" (2014) Caecilia Waha dan Sondakh Jemmy, "Pemenuhan Hak Atas Perumahan Yang Layak Bagi Masyarakat Miskin di Perkotaan (Suatu Kajian Dalam Perspektif Hak Asasi Manusia)" (2014) 1 Jurnal LPPM Bidang EkoSosBudKum $86<\mathrm{https}$ ://www.google.com/url?sa=t\&rct=j\&q=\&esrc=s\&-

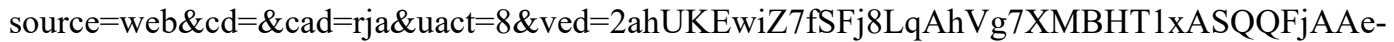
gQIBhAB\&url=https\%3A\%2F\%2Fejournal.unsrat.ac.id\%2Findex.php\%2Flppmekososbudkum\%2Farticle\%2Fview\%2F7222\&usg=AOvVaw1rXt-mQS_CeqyoG-0adKrc>.

9 Putra dan Yana (n 1).

10 Firdaus, "Pemenuhan Hak atas Perumahan yang Layak bagi Masyarakat Miskin Kota Dalam Perspektif HAM" (2016) 7 Jurnal HAM $85<$ http://ejournal.balitbangham.go.id/index.php/ ham/article/view/171>.
} 
perumahan bagi masyarakat miskin perkotaan dengan mengkaji regulasi serta implementasi yang dilakukan oleh pemerintah. Penelitian ini juga membandingkan regulasi dan implementasi yang dilakukan oleh Singapura dan Australia sebagai upaya pemenuhan hak masyarakat miskin perkotaan terhadap perumahan yang layak. Berdasarkan paparan latar belakang yang telah disajikan sebelumnya, maka dapat dirumuskan permasalahan yang akan dikaji dalam penelitian ini, yakni 1) Bagaimana pemenuhan hak masyarakat miskin perkotaan terhadap perumahan yang layak di Indonesia?: dan 2) Bagaimana negara Singapura dan Australia terhadap pemenuhan perumahan yang layak bagi masyarakat miskin perkotaan.

\section{Metode Penelitian}

Penelitian ini menggunakan metode penelitian hukum normatif dengan pendekatan comparative law antara negara Indonesia, Australia dan Singapura. Metode penelitian hukum normatif ini menggunakan data sekunder dengan teknik studi kepustakaan. Dalam mengkaji pemenuhan hak masyarakat miskin terhadap permukiman yang layak di perkotaan Indonesia menggunakan teknik analisis deskriptif-kualitatif untuk mendapatkan kesimpulan yang tepat.

\section{Pemenuhan Hak Masyarakat Miskin Perkotaan di Indonesia terhadap Perumahan dan Permukiman yang Layak}

Berkembangnya jumlah penduduk di perkotaan secara pesat membawa permasalahan yang krusial dalam pemenuhan kebutuhan rumah yang layak. ${ }^{11}$ Permasalahan itu bertambah, saat penduduk miskin masih belum mendapatkan perumahan yang layak untuk ditempati. Todaro dan Smith dalam buku Economic Development menyatakan bahwa variasi kemiskinan di negara berkembang disebabkan oleh beberapa faktor, yaitu: ${ }^{12}$ (1) perbedaan geografis, jumlah penduduk

\footnotetext{
${ }^{11}$ Vicky Makarauw, "Penduduk, Perumahan Pemukiman Perkotaan dan Pendekatan Kebijakan" (2012) 3 Jurnal Sabua $53<$ https://ejournal.unsrat.ac.id/index.php/SABUA/article/ view/239>.[53-55].

${ }^{12}$ Michael P Todaro dan Stephen C Smith, Economic development Twelve Edition (PEARSON 2015).[55-73].
} 
dan tingkat pendapatan, (2) perbedaan sejarah, sebagian dijajah oleh Negara yang berlainan, (3) perbedaan kekayaan sumber daya alam dan kualitas sumber daya manusianya, (4) perbedaan peranan sektor swasta dan negara, (5) perbedaan struktur industri, (6) perbedaan derajat ketergantungan pada kekuatan ekonomi dan politik negara lain dan (7) perbedaan pembagian kekuasaan, struktur politik dan kelembagaan dalam negeri.

Permasalahan kebutuhan rumah yanglayak bagimasyarakatmiskin merupakan urgensi yang harus disikapi dengan bijak oleh pemerintah. Menurut pandangan Festus dan Amos menyatakan bahwa kebijakan perumahan merupakan sebuah alat penting guna mendukung pembangunan nasional. ${ }^{13}$ Pemenuhan kebutuhan rumah yang layak sejatinya telah tertuang dalam naskah Konvenan Internasional tentang Hak Ekonomi, Sosial dan Budaya Pasal 11 ayat 1 yang mengemukakan bahwa kovenan ini mengakui hak setiap orang untuk mendapatkan kehidupan yang layak dengan mencakup pangan, sandang dan perumahan. Pemenuhan hak tersebut sejatinya harus difokuskan untuk memenuhi standar kehidupan yang layak sebagai wujud pemenuhan kesehatan dan kesejahteraan (the right to a standard of living adequate for health and well being). ${ }^{14}$ Berdasarkan Pasal 129 Undang-Undang Nomor 1 Tahun 2011 tentang Perumahan dan Kawasan Permukiman mengemukakan bahwa setiap warga negara berhak untuk memiliki perumahan yang sehat, aman, serasi dan teratur. Berdasarkan visi dan arah pembangunan jangka panjang (PJP) tahun 2005-2025 juga mengungkapkan pembangunan permukiman diarahkan untuk terciptanya: 1) Pembangunan berkelanjutan, memadai, layak dan terjangkau bagi masyarakat yang didukung oleh prasarana-sarana yang mencukupi dan berkualitas. 2) Terciptanya pembangunan perumahan dan prasarana-sarana permukiman yang mandiri, yang mampu untuk membangkitkan potensi pembiayaan yang bersumber dari masyarakat, menciptakan lapangan kerja, serta meningkatkan pemerataan

\footnotetext{
${ }^{13}$ Orthinus Ferdinando Samfar Kawer and others, "Implementasi Kebijakan Pembangunan Rumah Layak Huni Dengan Pendekatan Hibrida Di Kabupaten Supiori Provinsi Papua" (2018) 20 Sosiohumaniora.[245-246].

14 Yvette Basson, 'State obligations in international law related to the right to an adequate standard of living for persons with disabilities' (2017) 21 Law, Democracy \& Development.[79].
} 
dan penyebaran pembangunan. 3) terwujudnya pembangunan permukiman dan prasarana-sarana yang memperhatikan keseimbangan lingkungan hidup.

Lebih lanjut, kriteria rumah layak huni telah tertuang dalam penjelasan Pasal 24 huruf a Undang-Undang Nomor 1 Tahun 2011 tentang Perumahan dan Kawasan Permukiman yang menyatakan bahwa rumah layak huni harus memenuhi persyaratan keselamatan bangunan, kecukupan, minimum luas bangunan serta kesehatan penghuni. Pengertian keselamatan bangunan berdasarkan Pasal 17 Undang-Undang Nomor 28 Tahun 2002 tentang Bangunan Gedung harus meliputi kemampuan bangunan untuk mendukung beban muatan. Selanjutnya, menurut penelitian yang dilakukan oleh Pusat Penelitian dan Perkembangan Perumahan dan Permukiman tahun 2011 menyatakan minimal luas bangunan perumahan sederhana adalah 47,65 m2 dengan asumsi 1 keluarga terdiri atas 4 orang. ${ }^{15}$

Pemenuhan perumahan hak masyarakat miskin harus didasarkan terhadap 3 aspek ketersediaan, keterjangkauan dan kemudahan akses. ${ }^{16}$ Ketersediaan yang dimaksud perlu adanya ketersediaan layanan, material, fasilitas dan infrastruktur. Keterjangkauan yang dimaksud adalah keterjangkauan harga rumah terhadap masyarakat miskin baik berupa subsidi dan sebagainya. Kemudahan akses adalah perumahan dan lingkungan yang dapat diakses serta bermanfaat bagi setiap orang, dalam hal ini bagi kelompok yang rentan.

Oleh karena itu, sebagai upaya pemenuhan hak masyarakat miskin untuk mendapatkan rumah yang layak huni, pemerintah memiliki salah satu program diantaranya program satu juta rumah yang di mulai sejak tahun $2015 .{ }^{17}$ Program tersebut merupakan usaha pemerintah dalam wujud implementasi pemenuhan HAM pada pasal $28 \mathrm{H}$ ayat 1 . Selain itu, program ini juga menginisiasi UndangUndang Nomor 1 Tahun 2011 tentang Perumahan dan Kawasan Permukiman

15 Mahatma Sindu Suryo dan Puslitbang KemenPUPR, "Analysis of Minimum Space for Low Cost Landed House in indonesia" (2017) 12 Jurnal Permukiman $116<$ http://jurnalpermukiman. pu.go.id/index.php/JP/article/viewFile/62/pdf_1>.[117].

${ }^{16}$ Firdaus (n 10). [9-10].

${ }^{17}$ Rizki Washarti, "Satu juta rumah untuk rakyat Indonesia" (BBC News Indonesia, 2015) $<$ https://www.bbc.com/indonesia/majalah/2015/04/150426_bisnis_sejuta_rumah> diakses 25 Oktober 2020. 
Pasal 1 angka 24, yang mengungkapkan bahwa masyarakat berpenghasilan rendah (MBR) perlu mendapatkan dukungan pemerintah untuk memperoleh rumah. Program ini dinyatakan telah sukses melampaui target pada tahun 2019, dengan total jumlah 1.002.317 unit. $^{18}$ Namun, ditengah keberhasilan target, terdapat polemik didalamnya. Badan Pemeriksa Keuangan (BPK) mengungkapkan bahwa program ini mengalami ketidaktepatan sasaran dalam pelaksanaannya. ${ }^{19} \mathrm{Hal}$ ini ditunjukkan dalam Keputusan Menteri Pekerjaan Umum dan Perumahan Rakyat Nomor 242/ KPTS/M/2020 yang menetapkan gaji maksimum penerima subsidi satu juta rumah adalah 8 juta rupiah. Namun, dalam realisasinya, BPK menemukkan pelanggaran. ${ }^{20}$ Selain itu, program ini juga bermasalah di beberapa provinsi terkhusus di Papua. Masyarakat Papua memiliki gaji diatas 8 juta rupiah sesuai dengan upah minimum regional (UMR). Hal ini mengakibatkan realisasi program satu juta rumah di Papua hanya 5\%. Di sisi lain juga, keberhasilan program ini untuk memberikan perumahan yang layak bagi masyarakat miskin di perkotaan dapat dinyatakan tidak berhasil. Disisi lain, beberapa program pemerintah untuk menciptakan perumahan yang layak huni terhadap masyarakat miskin, seperti relokasi permukiman kumuh di Jakarta, Program Kota tanpa Kumuh dan beberapa program lainnya nyatanya juga tidak berhasil dan semakin meningkat pemukiman rumah kumuh di perkotaan. Hal tersebut dapat dilihat dari data dibawah ini:

Berkembangnya jumlah penduduk di perkotaan secara pesat membawa permasalahan yang krusial dalam pemenuhan kebutuhan rumah yang layak. ${ }^{21}$ Permasalahan itu bertambah, saat penduduk miskin masih belum mendapatkan perumahan yang layak untuk ditempati. Todaro dan Smith dalam buku Economic

\footnotetext{
18 Maulandy Rizky Bayu Kencana, "PUPR: Program Satu Juta Rumah Lampaui Target" (Liputan6.com) <https://www.liputan6.com/bisnis/read/4089849/pupr-program-satu-juta-rumahlampaui-target $>$ diakses 27 Oktober 2020.

19 Ferry Sandi, "Waduh! Ternyata Selama Ini Subsidi Rumah Banyak Salah Sasaran" (CNBC Indonesia, 2020) <https:/www.cnbcindonesia.com/news/20200723184421-4-175003/ waduh-ternyata-selama-ini-subsidi-rumah-banyak-salah-sasaran> diakses 26 Oktober 2020.

${ }^{20}$ ibid.

${ }^{21}$ Vicky Makarauw, "Penduduk, Perumahan Pemukiman Perkotaan dan Pendekatan Kebijakan” (2012) 3 Jurnal Sabua $53<$ https://ejournal.unsrat.ac.id/index.php/SABUA/article/ view/239>.[53-55].
} 
Development menyatakan bahwa variasi kemiskinan di negara berkembang disebabkan oleh beberapa faktor, yaitu: ${ }^{22}$ (1) perbedaan geografis, jumlah penduduk dan tingkat pendapatan, (2) perbedaan sejarah, sebagian dijajah oleh Negara yang berlainan, (3) perbedaan kekayaan sumber daya alam dan kualitas sumber daya manusianya, (4) perbedaan peranan sektor swasta dan negara, (5) perbedaan struktur industri, (6) perbedaan derajat ketergantungan pada kekuatan ekonomi dan politik negara lain dan (7) perbedaan pembagian kekuasaan, struktur politik dan kelembagaan dalam negeri.

Permasalahan kebutuhan rumah yang layak bagi masyarakat miskin merupakan urgensi yang harus disikapi dengan bijak oleh pemerintah. Menurut pandangan Festus dan Amos menyatakan bahwa kebijakan perumahan merupakan sebuah alat penting guna mendukung pembangunan nasional. ${ }^{23}$ Pemenuhan kebutuhan rumah yang layak sejatinya telah tertuang dalam naskah Konvenan Internasional tentang Hak Ekonomi, Sosial dan Budaya Pasal 11 ayat 1 yang mengemukakan bahwa kovenan ini mengakui hak setiap orang untuk mendapatkan kehidupan yang layak dengan mencakup pangan, sandang dan perumahan. Pemenuhan hak tersebut sejatinya harus difokuskan untuk memenuhi standar kehidupan yang layak sebagai wujud pemenuhan kesehatan dan kesejahteraan (the right to a standard of living adequate for health and well being). ${ }^{24}$ Berdasarkan Pasal 129 Undang-Undang Nomor 1 Tahun 2011 tentang Perumahan dan Kawasan Permukiman mengemukakan bahwa setiap warga negara berhak untuk memiliki perumahan yang sehat, aman, serasi dan teratur. Berdasarkan visi dan arah pembangunan jangka panjang (PJP) tahun 2005-2025 juga mengungkapkan pembangunan permukiman diarahkan untuk terciptanya: 1) Pembangunan berkelanjutan, memadai, layak dan terjangkau bagi masyarakat

${ }^{22}$ Michael P Todaro dan Stephen C Smith, Economic development Twelve Edition (PEARSON 2015).[55-73].

${ }^{23}$ Orthinus Ferdinando Samfar Kawer and others, "Implementasi Kebijakan Pembangunan Rumah Layak Huni Dengan Pendekatan Hibrida Di Kabupaten Supiori Provinsi Papua" (2018) 20 Sosiohumaniora 245.[245-246].

${ }^{24}$ Yvette Basson, "State obligations in international law related to the right to an adequate standard of living for persons with disabilities" (2017) 21 Law, Democracy \& Development 68.[79]. 
yang didukung oleh prasarana-sarana yang mencukupi dan berkualitas. 2) Terciptanya pembangunan perumahan dan prasarana-sarana permukiman yang mandiri, yang mampu untuk membangkitkan potensi pembiayaan yang bersumber dari masyarakat, menciptakan lapangan kerja, serta meningkatkan pemerataan dan penyebaran pembangunan. 3) terwujudnya pembangunan permukiman dan prasarana-sarana yang memperhatikan keseimbangan lingkungan hidup.

Lebih lanjut, kriteria rumah layak huni telah tertuang dalam penjelasan Pasal 24 huruf a Undang-Undang Nomor 1 Tahun 2011 tentang Perumahan dan Kawasan Permukiman yang menyatakan bahwa rumah layak huni harus memenuhi persyaratan keselamatan bangunan, kecukupan, minimum luas bangunan serta kesehatan penghuni. Pengertian keselamatan bangunan berdasarkan Pasal 17 Undang-Undang Nomor 28 Tahun 2002 tentang Bangunan Gedung harus meliputi kemampuan bangunan untuk mendukung beban muatan. Selanjutnya, menurut penelitian yang dilakukan oleh Pusat Penelitian dan Perkembangan Perumahan dan Permukiman tahun 2011 menyatakan minimal luas bangunan perumahan sederhana adalah 47,65 m2 dengan asumsi 1 keluarga terdiri atas 4 orang. ${ }^{25}$

Pemenuhan perumahan hak masyarakat miskin harus didasarkan terhadap 3 aspek ketersediaan, keterjangkauan dan kemudahan akses. ${ }^{26}$ Ketersediaan yang dimaksud perlu adanya ketersediaan layanan, material, fasilitas dan infrastruktur. Keterjangkauan yang dimaksud adalah keterjangkauan harga rumah terhadap masyarakat miskin baik berupa subsidi dan sebagainya. Kemudahan akses adalah perumahan dan lingkungan yang dapat diakses serta bermanfaat bagi setiap orang, dalam hal ini bagi kelompok yang rentan.

Oleh karena itu, sebagai upaya pemenuhan hak masyarakat miskin untuk mendapatkan rumah yang layak huni, pemerintah memiliki salah satu program

${ }^{25}$ Mahatma Sindu Suryo dan Puslitbang KemenPUPR, “Analysis of Minimum Space for Low Cost Landed House in indonesia" (2017) 12 Jurnal Permukiman $116<$ http://jurnalpermukiman. pu.go.id/index.php/JP/article/viewFile/62/pdf_1>.[117].

${ }^{26}$ Firdaus (n 10). [9-10]. 
diantaranya program satu juta rumah yang di mulai sejak tahun $2015 .{ }^{27}$ Program tersebut merupakan usaha pemerintah dalam wujud implementasi pemenuhan HAM pada pasal $28 \mathrm{H}$ ayat 1 . Selain itu, program ini juga menginisiasi UndangUndang Nomor 1 Tahun 2011 tentang Perumahan dan Kawasan Permukiman Pasal 1 angka 24, yang mengungkapkan bahwa masyarakat berpenghasilan rendah (MBR) perlu mendapatkan dukungan pemerintah untuk memperoleh rumah. Program ini dinyatakan telah sukses melampaui target pada tahun 2019, dengan total jumlah 1.002.317 unit. $^{28}$ Namun, ditengah keberhasilan target, terdapat polemik didalamnya. Badan Pemeriksa Keuangan (BPK) mengungkapkan bahwa program ini mengalami ketidaktepatan sasaran dalam pelaksanaannya. ${ }^{29} \mathrm{Hal}$ ini ditunjukkan dalam Keputusan Menteri Pekerjaan Umum dan Perumahan Rakyat Nomor 242/ KPTS/M/2020 yang menetapkan gaji maksimum penerima subsidi satu juta rumah adalah 8 juta rupiah. Namun, dalam realisasinya, BPK menemukkan pelanggaran. ${ }^{30}$ Selain itu, program ini juga bermasalah di beberapa provinsi terkhusus di Papua. Masyarakat Papua memiliki gaji diatas 8 juta rupiah sesuai dengan upah minimum regional (UMR). Hal ini mengakibatkan realisasi program satu juta rumah di Papua hanya 5\%. Di sisi lain juga, keberhasilan program ini untuk memberikan perumahan yang layak bagi masyarakat miskin di perkotaan dapat dinyatakan tidak berhasil. Disisi lain, beberapa program pemerintah untuk menciptakan perumahan yang layak huni terhadap masyarakat miskin, seperti relokasi permukiman kumuh di Jakarta, Program Kota tanpa Kumuh dan beberapa program lainnya nyatanya juga tidak berhasil dan semakin meningkat pemukiman rumah kumuh di perkotaan. Hal tersebut dapat dilihat dari data dibawah ini:

\footnotetext{
${ }^{27}$ Rizki Washarti, "Satu juta rumah untuk rakyat Indonesia” (BBC News Indonesia, 2015) $<$ https://www.bbc.com/indonesia/majalah/2015/04/150426_bisnis_sejuta_rumah $>$ diakses 25 Oktober 2020.

28 Maulandy Rizky Bayu Kencana, "PUPR: Program Satu Juta Rumah Lampaui Target" (Liputan6.com) $<$ https://www.liputan6.com/bisnis/read/4089849/pupr-program-satu-juta-rumahlampaui-target> diakses 27 Oktober 2020.

29 Ferry Sandi, "Waduh! Ternyata Selama Ini Subsidi Rumah Banyak Salah Sasaran" (CNBC Indonesia, 2020) < https:/www.cnbcindonesia.com/news/20200723184421-4-175003/ waduh-ternyata-selama-ini-subsidi-rumah-banyak-salah-sasaran> diakses 26 Oktober 2020.

${ }^{30}$ ibid.
} 
Brillian Aditya: Pemenuhan Hak Masyarakat...

Tabel 1. Tingkat Rumah Kumuh di Perkotaan Indonesia ${ }^{31}$

\begin{tabular}{|c|c|c|c|}
\hline \multirow[t]{2}{*}{ Provinsi } & \multicolumn{3}{|c|}{$\begin{array}{c}\text { Persentase Rumah Tangga Kumuh Perkotaan ( } 40 \% \mathrm{Ke} \\
\text { Bawah), Menurut Provinsi (Persen) }\end{array}$} \\
\hline & 2019 & 2018 & 2017 \\
\hline SUMATERA UTARA & 10,00 & 8,74 & 8,25 \\
\hline SUMATERA SELATAN & 17,87 & 12,68 & 11,22 \\
\hline SUMATERA BARAT & 10,52 & 9,36 & 9,97 \\
\hline SULAWESI UTARA & 13,90 & 12,92 & 8,41 \\
\hline SULAWESI TENGGARA & 9,35 & 11,16 & 13,49 \\
\hline SULAWESI TENGAH & 17,08 & 14,63 & 9,37 \\
\hline SULAWESI SELATAN & 11,59 & 7,74 & 5,82 \\
\hline SULAWESI BARAT & 15,68 & 15,22 & 22,66 \\
\hline RIAU & 7,50 & 3,36 & 5,80 \\
\hline PAPUA BARAT & 16,04 & 14,55 & 20,65 \\
\hline PAPUA & 18,89 & 17,00 & 12,48 \\
\hline NUSA TENGGARA TIMUR & 31,54 & 16,15 & 23,21 \\
\hline NUSA TENGGARA BARAT & 15,01 & 10,90 & 9,97 \\
\hline MALUKU UTARA & 4,76 & 6,93 & 4,25 \\
\hline MALUKU & 16,26 & 14,72 & 19,09 \\
\hline LAMPUNG & 14,31 & 4,33 & 4,44 \\
\hline KEP. RIAU & 17,48 & 5,70 & 3,43 \\
\hline KEP. BANGKA BELITUNG & 21,94 & 5,13 & 3,41 \\
\hline KALIMANTAN UTARA & 12,57 & 9,52 & 13,12 \\
\hline KALIMANTAN TIMUR & 6,07 & 5,93 & 7,37 \\
\hline KALIMANTAN TENGAH & 15,46 & 8,88 & 9,78 \\
\hline KALIMANTAN SELATAN & 14,86 & 10,07 & 7,81 \\
\hline KALIMANTAN BARAT & 6,60 & 4,01 & 7,93 \\
\hline JAWA TIMUR & 8,38 & 4,06 & 3,40 \\
\hline JAWA TENGAH & 9,02 & 3,21 & 3,53 \\
\hline JAWA BARAT & 19,86 & 11,16 & 11,86 \\
\hline JAMBI & 7,80 & 5,21 & 5,99 \\
\hline GORONTALO & 14,16 & 12,83 & 15,13 \\
\hline DKI JAKARTA & 42,73 & 14,36 & 14,55 \\
\hline DI YOGYAKARTA & 3,79 & 2,77 & 3,95 \\
\hline BENGKULU & 14,56 & 9,13 & 14,85 \\
\hline BANTEN & 16,81 & 4,70 & 5,70 \\
\hline BALI & 5,19 & 2,75 & 2,74 \\
\hline $\mathrm{ACEH}$ & 10,18 & 9,12 & 8,10 \\
\hline INDONESIA & 13,86 & 7,42 & 7,62 \\
\hline
\end{tabular}

${ }^{31}$ Badan Pusat Statistik (n 3). 


\section{Pemenuhan Hak Masyarakat Miskin terhadap Tempat Tinggal yang Layak di} Singapura dan Australia

\section{A. Singapura}

Dalam sejarahnya, Singapura merupakan bekas jajahan Inggris. Negara ini mengadakan pemilihan umum pertamanya sebagai negara berpemerintahan sendiri sepenuhnya pada tahun 1959, kemudian bergabung dengan Federasi Malaysia pada tahun 1963, dan menjadi republik merdeka pada tahun $1965 .{ }^{32}$ Singapura merupakan salah satu negara terkaya di dunia. Meski begitu, masalah sosial berupa kemiskinan dan kurangnya kelayakan tempat tinggal untuk masyarakat dan warga negara masih ditemukan.

Singapura mengatur Hak warga negaranya melalui The Constitution of The Republic of Singapore yang didalamnya mengatur mengenai hak-hak seperti hak hidup [Pasal 9 ayat (1)]; Hak mendapat bantuan hukum [Pasal 9 ayat (2)]; Hak rehabilitas dan pelayanan untuk narapidana penyalahgunaan narkoba pasal [9 ayat (6) huruf b]; Hak merdeka dari perbudakan dan forced labour [Pasal 10]; Hak untuk tidak dapat dipidana bila tidak ada hukum yang dibuat dan/atau diatur (asas Legalitas) [Pasal 11]; Hak Perlindungan yang sama dan setara [Pasal 12]; Perlakuan yang sama di mata hukum [Pasal 12 ayat (1)]; Hak kebebasan menyampaikan pendapat, berbicara, berekspresi, berkumpul dan berorganisasi selama tidak melanggar kepentingan dan keamanan negara [Pasal 14]; Hak kebebasan beragama [Pasal 15]; Hak mendapat pendidikan yang baik dan layak [Pasal 16]; Hak Kewarganegaraan [Pasal 120-139]; Hak Kewarganegaraan Commonwealth [Pasal 139]; Hak menjadi berpartisipasi dalam pemerintahan [Pasal 39A]; Hak posisi spesial untuk orang Malaysia [Pasal 152].

Pada Pasal 13 Ayat (2) memberikan Hak untuk bergerak bebas dan bertempat tinggal. Selain dalam konstitusi, Singapura memiliki undang-undang yang berperan penting dalam resolusi kebijakan perumahan dan lahan. Pemerintah menaruh banyak perhatian pada amandemen undang-undang tentang Akusisi Lahan oleh negara dari

32 Stephan Ortmann, "Singapore : The Politics of Inventing" (2009) 28 Journal of Current Southeast Asian Affairs $23<$ www.CurrentSoutheastAsianAffairs.org>.[27]. 
awal 1960-an. Undang-Undang Akusisi Lahan tahun 1966 adalah langkah penting dalam kebijakan perumahan dan pembangunan ekonomi Singapura dan memiliki efek redistribusi yang besar.

Dalam Undang-Undang Akusisi Lahan, yang disahkan pada tahun 1966, terdapat pengaturan di mana negara diberi kekuasaan yang luas untuk memperoleh tanah, yakni:

a. untuk tujuan publik apa pun;

b. oleh setiap orang, perusahaan atau badan hukum, untuk setiap pekerjaan atau usaha yang, menurut Menteri, adalah untuk kepentingan umum atau kegunaan umum atau untuk kepentingan umum; atau

c. untuk tujuan perumahan, komersial atau industri.

Melalui UU tersebut, pemerintah diperbolehkan membeli lahan dengan harga murah guna membuat proyek perumahan. Pada awalnya perumahan tersebut hanya disewakan saja, namun kemudian Lee Kuan Yew, perdana menteri pada 1960 an sekaligus Perdana Menteri yang mengakomodir UU tersebut, menegaskan untuk memiliki perumahan tersebut sebagai prioritas nasional. ${ }^{33}$ Hal tersebut bertujuan untuk membantu stabilitas nasional.

Salah satu kebijakan yang dilakukan oleh pemerintah Singapura adalah melalui Lembaga Pembangunan Perumahan atau Housing Development Board (HDB), yang sudah disebutkan di atas, yang merupakan lembaga Negara di bawah naungan Kementrian Pembangunan Nasional Singapura yang bertugas di bidang perumahan di Singapura. ${ }^{34}$

Pada tahun 1960-an saat Singapura baru merdeka, penduduknya 1,89 juta, sekitar 1,3 juta di antaranya miskin dan hidup di kawasan kumuh, termasuk di bantaran-bantaran sungai, atau di mana saja yang bisa digunakan untuk membangun pemukiman. Merespon masalah sosial tersebut, HDB lahir pada tahun 1960an

33 Sarah Keating, "Kisah Singapura dengan program perumahan umum yang dianggap paling sukses di dunia" (BBC News Indonesia, 2019) <https://www.bbc.com/indonesia/vertcap-46755795> diakses 29 Oktober 2020.

34 Denis Bocquet, "Living in Singapore: Housing Policies between Nation-building Processes , Social Control and the Market" [2015] Territorio 35.[36-37]. 
dalam masa kepemimpinan Lee Kuan Yew yang merupakan program resolusi dari permasalahan sosial yang disebutkan di atas, salah satunya berupa hak rakyat atas tempat tinggal yang layak, membangun banyak flat guna memenuhi kebutuhan tempat tinggal warga Singapura.

Langkah awal dari program HDB adalah langkah yang diambil pemerintah Singapura merelokasi penduduknya dari pemukiman-pemukiman kumuh, pengosongan lahan-lahan kumuh, bangunan-bangunannya dibongkar, kemudian mengalih fungsi lahan-lahan yang ditinggalkannya itu menjadi pusat bisnis, taman kota, obyek wisata, infrastruktur jalan. Untuk keperluan itu pemerintah Singapura pun membangun pulau seluas sekitar 500 kilometer persegi (sebelum melakukan reklamasi) menjadi kota taman, di atasnya dibangun apartemen atau rumah-rumah susun yang representatif, dilengkapi dengan prasarana pendidikan dan kesehatan, dengan prinsip setiap keluarga harus punya rumah dengan lingkungan yang bersih dan higienis. ${ }^{35}$ Substansi utama pembangunan tersebut adalah mengkombinasikan program penyediaan rumah susun dengan angkutan publik, lapangan pekerjaan, fasilitas pendidikan, kesehatan, dan kebutuhan dasar lainnya, seperti ketercukupan bahan pangan.

Lahan-lahan bekas pemukiman kumuh itu pun disediakan untuk membangun berbagai prasarana dan sarana, infrastruktur, taman kota, dan seterusnya untuk diubah menjadi kawasan pusat bisnis, perekonomian, dan obyek wisata kelas dunia. Sistem perumahan ini memiliki 75\% dari stok perumahan pada tahun 2015 yang diklasifikasikan sebagai "perumahan umum" yang dibangun terutama oleh HDB; $82 \%$ penduduk tinggal di perkebunan $\mathrm{HDB}$, dimana 79\% tinggal di perumahan yang dijual HDB. Permintaan untuk kepemilikan rumah didorong oleh sistem dana pensiun perumahan yang diperkenalkan pada tahun 1968 ketika tabungan Central Provident Fund ${ }^{36}$ (CPF) diizinkan untuk digunakan sebagai uang muka dan

\footnotetext{
${ }^{35}$ Nuran Wibisono, "Dari Kampung Menuju Rusun dan Apartemen" (Tirto.id, 2017) <https:// tirto.id/dari-kampung-menuju-rusun-dan-apartemen-cj3o> diakses 29 Oktober 2020.

${ }^{36}$ Sebuah simpanan yang wajib dimiliki oleh warga Singapura yang telah bekerja dan wajib membayar simpanan tersebut.
} 
pembayaran hipotek untuk flat/apartemen HDB. ${ }^{37}$

Kehadiran HDB berhasil menghilangkan permukiman kumuh dan merelokasi penghuninya ke blok-blok apartemen yang kecil, bersih, dan modern. HDB telah berperan membantu menjaga harga dan biaya perumahan Singapura jauh lebih masuk akal dibandingkan harga perumahan di kotakota utama Tiongkok Hongkong, atau Tokyo. HDB bahkan menjadi tulang punggung percepatan pembangunan ruang kota. Pada 2013, tingkat kepemilikan rumah di Singapura tertinggi di dunia, yaitu 90,5 persen. ${ }^{38}$ Pembangunan perumahan rakyat vertikal digabungkan dengan perencanaan terintegrasi fasilitas dan utilitas publik, Rancangan jalan, fasilitas publik seperti sekolah, taman dan pasar, diimplementasikan dengan standar dan rasio yang ketat. Singapura menjadi tujuan dan basis perusahaan multinasional. Sebuah studi yang dilakukan Roland Berger pada 2011 menyebut Singapura sebagai lokasi utama untuk perusahaan-perusahaan Eropa mendirikan kantor pusat wilayah Asia Pasifik dan perusahaan Amerika, seperti Microsoft, Google, dan Kellogg. ${ }^{39}$

\section{B. Australia}

Australia adalah salah satu negara yang menandatangani Sustainable Development Goals (SDGs) PBB di mana poin pertama dari SDGs ini adalah "No Poverty", atau tanpa kemiskinan. Namun nyatanya, menurut International Monetary Fund 2019 mengungkapkan Australia menempati peringkat keempat dari 22 negara maju di dunia yang memiliki jurang perbedaan ekonomi antara yang kaya dan miskin. ${ }^{40}$ Tingkat kemiskinan yang tinggi ini mempengaruhi segala faktor

\footnotetext{
37 Sock-yong Phang dan Matthias Helble, Housing Policies in Singapore (Tokyo ed, Asian Development Bank Institute 2016).[3].

${ }^{38}$ Hilda B Alexander, “Singapura Kota Tersukses Dunia, Jakarta Malah 'Dikerjain' Pengembang” (Kompas.com, 2015) <https://properti.kompas.com/read/2015/03/23/135858621/Singapura. Kota.Tersukses.Dunia.Jakarta.Malah.Dikerjain.Pengembang.?page=all\#: :text=Menurut Ketua Umum Ikatan Ahli,5 persen pada tahun 2013.> diakses 29 Oktober 2020.

${ }^{39}$ ibid.

40 Australian Council of Social Services, "Poverty in Australia 2020 Part 2: Who is Affected?" (2020) <http://povertyandinequality.acoss.org.au/wp-content/uploads/2020/02/Poverty-in-Australia-2020_Part-1_Overview.pdf $>$.
} 
kehidupan warga Australia, tak terkecuali tak layaknya rumah yang masyarakat Australia huni. ${ }^{41}$ Associate Professor Bruce Bradbury, peneliti di UNSW Social Policy Research Centre, menjabarkan penyebab terjadinya kemiskinan di Australia dalam video discuss the 2020 Poverty in Australia, yakni: ${ }^{42}$

1. Pembayaran awal baru atas tunjangan sosial untuk orang-orang yang pengangguran dilakukan secara konstan;

2. Biaya perumahan yang naik;

3. Jatuhnya tingkat kepemilikan rumah dan harga sewa rumah naik.

Hal ini sejalan dengan yang disampaikan oleh CEO ACOSS, Cassandra Goldie yang mengungkapkan bahwa warga Australia terperangkap dalam kemiskinan akibat rendahnya tunjangan sosial, kurangnya pekerjaan, serta mahalnya biaya tempat tinggal. ${ }^{43}$ Di Australia, terdapat lembaga Australian Council of Social Service (ACOSS) yang dalam hal ini bekerja sama dengan University of New South Wales untuk mengatasi permasalahan kemiskinan di Australia. Pada program ini, ${ }^{44}$ ACOSS dan UNSW menggunakan dua garis kemiskinan internasional untuk mengukur kemiskinan di Australia. Dalam laporannya, ACOSS dan UNSW secara mayoritas perhitungannya menggunakan 'pasca biaya perumahan'. Hal ini dikarenakan perumahan adalah biaya tetap terbesar bagi sebagian besar rumah tangga. ${ }^{45}$

41 ibid.[20-22].

42 BELINDA HENWOOD, "UNSW and ACOSS report shows 3m Australians living in poverty" (Newsroom.com, 2020) < https://newsroom.unsw.edu.au/news/social-affairs/unsw-andacoss-report-shows-3m-australians-living-poverty\#: :text=UNSW and ACOSS report shows 3m Australians living in poverty,-Twitter Facebook LinkedIn\&text=It shows more than 3.24, week for a single adult> diakses 28 Oktober 2020.

43 Maggie Coggan, "Over 3 million Australians locked into poverty" (Probonoaustralia. com, 2020) <https://probonoaustralia.com.au/news/2020/02/over-3-million-australians-lockedinto-poverty/> diakses 29 Oktober 2020.

44 ACOSS / UNSW bekerja sama dalam ACOSS/UNSW Sydney Poverty and Inequality Partnership, yang merupakan penelitian 5 tahun dan kolaborasi dampak yang menggabungkan penelitian berkualitas dengan advokasi yang efektif untuk perubahan sistemik. Mitra termasuk peneliti kebijakan sosial, kesehatan, hukum, dan perumahan terkemuka, dengan penyedia layanan sosial utama dan pendukung dari keanggotaan ACOSS.

${ }^{45}$ Rumah tangga dengan biaya perumahan yang lebih rendah mampu memiliki standar hidup yang lebih tinggi daripada mereka yang berpenghasilan sama dengan biaya perumahan yang lebih tinggi. 
ACOSS dan UNSW menemukan bahwa terdapat 3,24 juta orang $(13,6 \%)$ hidup di bawah garis kemiskinan, sebesar 50\% dari pendapatan rata-rata - termasuk 774.000 anak-anak $(17,7 \%)$ dan 424.800 orang muda (13,9\%). Dalam angka dolar, garis kemiskinan ini menghasilkan $\$ 457$ atau $\mathrm{Rp}$. 4.770 .032 tiap pekan untuk satu orang dewasa yang hidup sendiri; atau \$ 960 atau Rp.10.025.116 tiap pekan untuk pasangan dengan 2 anak. $^{46}$ DAVIACOSS dan UNSW juga menemukan bahwa mayoritas $(56 \%)$ orang di bawah garis kemiskinan menyewa rumah untuk tempat tinggalnya, sementara hanya $17 \%$ orang dalam kemiskinan yang merupakan pemilik rumah yang tidak memiliki Kredit Kepemilikan Rumah. ${ }^{47}$ Dari temuan tersebut, dapat kita simpulkan bahwa secara de facto, faktor utama yang menentukan status kemiskinan lansia adalah status perumahan mereka: 41\% penyewa berusia 65 ke atas berada dalam kemiskinan, dibandingkan dengan hanya $10 \%$ dari semua orang yang berusia $65 \mathrm{ke}$ atas.

Konstitusi Australia ini juga merupakan bentuk penetapan Australia sebagai federasi dari Inggris. Dalam konstitusinya, tercermin hak masyarakat tentang hak penduduk Australia pada Pasal 117 Rights of Residents in States yang berbunyi:

"A subject of the Queen, resident in any State, shall not be subject in any other State to any disability or discrimination which would not be equally applicable to him if he were a subject of the Queen resident in such other State".

Dari Pasal tersebut, kita dapat mengetahui bahwa setiap subjek dari penduduk Ratu, yang bertempat tinggal di Negara Bagian mana pun, tidak akan tunduk pada kecacatan atau diskriminasi apa pun di Negara lain mana pun yang tidak berlaku sama baginya jika dia adalah subjek dari penduduk Ratu di Negara lain tersebut. Sebagai kesimpulan, warga negara Australia tidak memiliki perlindungan konstitusional terkait hal-hal fundamental dan menjadi masalah sosial seperti kemiskinan, dan pemenuhan kebutuhan tempat tinggal yang layak.

${ }^{46}$ Peter Davidson and others, "Poverty in Australia 2020: Part 1, Overview" (2020)<http:// povertyandinequality.acoss.org.au/wp-content/uploads/2020/02/Poverty-in-Australia-2020_Part1_Overview.pdf $>$.[12-14].

${ }^{47}$ Australian Council of Social Services (n 30).[20-28]. 
Dalam hukum internasional, hak atas perumahan (tempat tinggal) yang layak merupakan hak asasi manusia yang diakui di dunia internasional hukum hak asasi manusia sebagai bagian dari hak atas standar hidup yang layak. ${ }^{48}$ Meski tiada pengaturan dan perlindungan konstitusional atas hak tempat tinggal yang layak, pemerintah Australia memperhatikan masalah sosial tersebut. ACOSS dan UNSW dalam penelitiannya menunjukkan peran yang dimainkan oleh kebijakan publik - terutama jaminan sosial dan perpajakan, tetapi juga kebijakan perumahan dan ketenagakerjaan, di antara bidang lainnya - dalam menentukan tingkat kemiskinan dan ketidaksetaraan di Australia.

ACOSS telah mengembangkan serangkaian proposal reformasi kebijakan untuk mengatasi kemiskinan dan ketidaksetaraan di Australia di bidang-bidang berikut: (1). Pelayanan masyarakat yang berkualitas; (2) Tindakan terhadap perubahan iklim dan energi bersih yang terjangkau; (3) Ekonomi \& pajak; (4) Dukungan pendapatan \& pekerjaan; (5) Pelayanan kesehatan yang berkualitas untuk semua yang membutuhkan; (6) Perumahan \& tunawisma.

Dalam hal pemenuhan hak rumah yang layak, Pemerintah Australia telah membuat beberapa program seperti Australians for Affordable Housing. Program Australians for Affordable Housing telah didirikan dengan koalisi lebih dari 60 perumahan nasional, organisasi kesejahteraan dan sektor masyarakat yang menekankan pada masalah keterjangkauan perumahan. ${ }^{49}$ The Australians for Affordable Housing menyarankan semua tingkat pemerintahan untuk melakukan perubahan yang diperlukan guna memastikan tersedianya perumahan yang terjangkau bagi semua warga Australia. Akibatnya, pemerintah di semua tingkatan mempengaruhi pasar perumahan melalui insentif pajak, hibah pemilik rumah

${ }^{48}$ Bret Thiele, "The human right to adequate housing: A tool for promoting and protecting individual and community health" (2002) 92 American Journal of Public Health.[712].

49 John McLaren, Allan Yeo dan Michael Sweet, "Australia is facing a housing affordability crisis: Is the solution to this problem the Singapore model of housing?" (2016) 10 Australasian Accounting, Business and Finance Journal 43. Hlm. 43-45.; Shah and Mishra.A.K, "Review on Global Practice of Housing Demand Fulfillment for Low Income Group People" (2018) 1 NOLEGEIN Journal of Business Ethics, Ethos \& CSR < https://www.researchgate.net/publication/329164106_ Review_on_Global_Practice_of_Housing_Demand_Fulfilment_for_Low_Income_Group_People>. Him. $\overline{10}-12$. 
pertama, program perumahan yang terjangkau, pengendalian perencanaan dan dukungan sewa. Selain itu, ada Community Housing, merupakan salah satu jenis Social Housing (bersama Public Housing dan Affordable Housing). Community Housing adalah akomodasi sewa jangka panjang yang disediakan oleh organisasi komunitas nirlaba. ${ }^{50}$ Community Housing menerima bantuan dari Pemerintah dalam bentuk hibah, pinjaman, tempat tinggal, atau pendanaan operasional saat ini. Hal yang ditawarkan oleh Community Housing adalah perumahan sewa jangka panjang bagi orang-orang dengan pendapatan rendah hingga sedang dengan kebutuhan perumahan. Penyewa Community Housing memiliki hak banding seperti penyewa Public Housing. ${ }^{51}$ Ketika seorang penyewa Community Housing dipengaruhi oleh keputusan yang dibuat oleh organisasi Community Housing, mereka dapat mengajukan banding ke organisasi tersebut.

Jika memenuhi syarat, beberapa organisasi Community Housing meminta penyewa untuk membayar dengan jumlah yang setara hingga 100\% dari hak Commonwealth Rent Assistance. Beberapa organisasi Community Housing juga menawarkan opsi berbagi kelompok, di mana penyewa mendapat kamar tidur pribadi dengan fasilitas lain (seperti kamar mandi, dapur, dan binatu) dapat digunakan bersama. Beberapa organisasi Community Housing juga menawarkan 'Affordable Housing' di mana sewa lebih murah 74,9\% dari harga sewa pasar. ${ }^{52}$

Manfaat lain yang ditawarkan oleh Community Housing adalah persediaan beragam pilihan pilihan perumahan yang mencerminkan kebutuhan dan preferensi yang berbeda warga. Penyedia Community Housing juga memberikan layanan pribadi yang membantu warga dengan masalah terkait dengan masa sewa tiap warganya. Sebagian besar penyewa Community Housing membayar sewa yang serupa dengan penyewa perumahan publik (25\% dari pendapatan rumah tangga)

50 ACT Government, "What is Community Housing ? - important information from Housing ACT"(1997) < https://www.communityservices.act.gov.au/hcs/policies/fact_sheets/whatis-community-housing $>$.[1-4].

${ }^{51}$ Saat penyewa Public Housing dipengaruhi oleh keputusan yang dibuat oleh Housing ACT, mereka dapat mengajukan banding ke Housing ACT.

52 Power Housing Australia, "Australian affordable housing report" (2020).[26-29]. 
atau sewa pasar untuk properti tertentu, yang tentu lebih rendah.

Saat ini, terdapat lima organisasi perumahan masyarakat yang memberikan laporan perumahan jangka panjang kepada Pemerintah ACT (Australian Capital Territory), yakni: $:^{53}$

- Argyle Community Housing;

- Environmental Community Housing Organisation (ECHO);

- Havelock Housing Association (HHA);

- Salvos Housing;

- Tamil Senior Citizens Association.

Warga Australia juga dapat mendaftar kedua Housing (Community Housing dan Public Housing). yang akan warga terdaftar untuk keduanya di Social Housing Register yang dikelola oleh Housing ACT. Setelah terdaftar, warga masuk ke Daftar Perumahan Sosial dan dialokasikan perumahan bantuan atas dasar kebutuhan dan kesesuaian dengan properti yang tersedia

\section{Kesimpulan}

Pemenuhan masyarakat miskin di perkotaan terhadap perumahan yang layak merupakan tugas dari pemerintahan. Namun, ditengah banyaknya kebijakan sebagai upaya jaminan rumah layak, nampaknya masih belum terwujud dan terimplikasikan oleh pemerintah. Padahal beberapa program telah dijalankan oleh pemerintah untuk mengatasi hal tersebut, namun tingkat perumahan yang tidak layak semakin meningkat. Dengan melihat perbandingan Singapura dan Australia, tentunya dapat memberikan pandangan bagi pemerintah Indonesia untuk melakukan kebijakan yang tepat dalam penanganan hal ini. Di Singapura yang awalnya menjadi negara kumuh, kini menjadi negara terbersih dan tanpa rumah kumuh. Di sisi lain, Australia yang sedang menghadapi hal yang sama seperti Indonesia, melakukan dobrakan besar seperti affordable housing, community housing dan beberapa kebijakan lainnya.

${ }^{53}$ ACT Government (n 40). [2-4]. 


\section{Daftar Bacaan}

\section{Buku}

ACT Government, "What is Community Housing ? - important information from Housing ACT" (1997) https://www.communityservices.act.gov.au/hcs/ policies/fact_sheets/what-is-community-housing.

Australian Council of Social Services, "Poverty in Australia 2020 Part 2: Who is Affected?" (2020) http://povertyandinequality.acoss.org.au/wp-content/ uploads/2020/02/Poverty-in-Australia-2020_Part-1_Overview.pdf.

Davidson P and others, "Poverty in Australia 2020: Part 1, Overview" (2020) $<$ http:// povertyandinequality.acoss.org.au/wp-content/uploads/2020/02/Poverty-inAustralia-2020_Part-1_Overview.pdf $>$.

Phang S dan Helble M, Housing Policies in Singapore (Tokyo ed, Asian Development Bank Institute 2016).

Power Housing Australia, "Australian affordable housing report” (2020).

Todaro MP dan Smith SC, Economic development Twelve Edition (PEARSON 2015).

\section{Jurnal}

Basson Y, "State obligations in international law related to the right to an adequate standard of living for persons with disabilities" (2017) 21 Law, Democracy \& Development 68.

Bocquet D, "Living in Singapore: Housing Policies between Nation-building Processes, Social Control and the Market" [2015] Territorio 35.

Firdaus, "Pemenuhan Hak atas Perumahan yang Layak bagi Masyarakat Miskin Kota Dalam Perspektif HAM” (2016) 7 Jurnal HAM 85 http://ejournal. balitbangham.go.id/index.php/ham/article/view/171.

Joo TTK dan Wong TC, "Public housing in singapore: A sustainable housing form and development" [2008] Springer 135.

Kawer OFS and others, "Implementasi Kebijakan Pembangunan Rumah Layak Huni Dengan Pendekatan Hibrida Di Kabupaten Supiori Provinsi Papua" (2018) 20 Sosiohumaniora 245.

Makarauw V, "Penduduk, Perumahan Pemukiman Perkotaan dan Pendekatan Kebijakan" (2012) 3 Jurnal Sabua $53<$ https://ejournal.unsrat.ac.id/index. 
php/SABUA/article/view/239>.

McLaren J, Yeo A dan Sweet M, "Australia is facing a housing affordability crisis: Is the solution to this problem the Singapore model of housing?" (2016) 10 Australasian Accounting, Business and Finance Journal 43.

Ortmann S, "Singapore : The Politics of Inventing" (2009) 28 Journal of Current Southeast Asian Affairs $23<$ www.CurrentSoutheastAsianAffairs.org>.

Putra IDGAD dan Yana AAG, "Pemenuhan Atas Perumahan Salah Satu Upaya Penanggulangan Kemiskinan” (2007) 5 Jurnal Pemukiman Natah 103.

Shah and Mishra.A.K, "Review on Global Practice of Housing Demand Fulfillment for Low Income Group People" (2018) 1 NOLEGEIN Journal of Business Ethics, Ethos \& CSR < https://www.researchgate.net/publication/329164106_ Review_on_Global_Practice_of_Housing_Demand_Fulfilment_for_Low_ Income_Group_People>.

Thiele B, "The human right to adequate housing: A tool for promoting and protecting individual and community health" (2002) 92 American Journal of Public Health 712.

Ulu V dan Sholichah N, "Evaluasi Program Rehabilitasi Sosial Daerah Kumuh Terhadap PeningkaTan Kualitas Hidup Warga di Kelurahan Ngagelrejo, Kecamatan Wonokromo Kota Surabaya" (2020) 4 Jurnal Asketik: Agama dan Perubahan Sosial 85.

Waha C dan Jemmy S, "Pemenuhan Hak Atas Perumahan Yang Layak Bagi Masyarakat Miskin di Perkotaan (Suatu Kajian Dalam Perspektif Hak Asasi Manusia)" (2014) 1 Jurnal LPPM Bidang EkoSosBudKum 86.

Wilson L and others, "National housing policy in Australia: Are new initiatives in affordable housing sustainable?" (2010) 5 International Journal of Interdisciplinary Social Sciences 129.

\section{Laman}

Alexander HB, "Singapura Kota Tersukses Dunia, Jakarta Malah 'Dikerjain' Pengembang" (Kompas.com, 2015) <https://properti.kompas.com/ $\mathrm{read} / 2015 / 03 / 23 / 135858621 /$ Singapura.Kota.Tersukses.Dunia.Jakarta. Malah.Dikerjain.Pengembang.?page=all\#: :text=Menurut Ketua Umum Ikatan Ahli,5 persen pada tahun 2013.> diakses 29 Oktober 2020.

Badan Pusat Statistik, "Persentase Rumah Tangga Kumuh Perkotaan $(40 \% \mathrm{Ke}$ Bawah), Menurut Provinsi (Persen), 2017-2019” (2019)<https://www.bps. 
go.id/indicator/23/1561/1/persentase-rumah-tangga-kumuh-perkotaan-40ke-bawah-menurut-provinsi.html> diakses 25 Oktober 2020.

\section{BAGIAN HUKUM DAN KOMUNIKASI PUBLIK DITJEN PENYEDIAAN} PERUMAHAN KEMENTERIAN PUPR, "Kementerian PUPR Tetapkan 4 Kriteria Rumah Layak Huni” (2020) <https://perumahan.pu.go.id/berita/ view/212/kementerian-pupr-tetapkan-4-kriteria-rumah-layak-huni> diakses 25 Oktober 2020.

Coggan M, "Over 3 million Australians locked into poverty" (Probonoaustralia. com, 2020) $<$ https://probonoaustralia.com.au/news/2020/02/over-3-millionaustralians-locked-into-poverty/> diakses 29 Oktober 2020.

detikNews, "Mereka yang Ubah Daerah Kumuh di Berbagai Negara Jadi Permukiman Layak" (2019) <https://news.detik.com/bbc-world/d-4426586/ mereka-yang-ubah-daerah-kumuh-di-berbagai-negara-jadi-permukimanlayak> diakses 26 Oktober 2020.

HENWOOD B, "UNSW and ACOSS report shows 3m Australians living in poverty" (Newsroom.com, 2020) <https://newsroom.unsw.edu.au/news/ social-affairs/unsw-and-acoss-report-shows-3m-australians-livingpoverty\#: :text=UNSW and ACOSS report shows $3 \mathrm{~m}$ Australians living in poverty,-Twitter Facebook LinkedIn\&text=It shows more than 3.24,week for a single adult $>$ diakses 28 Oktober 2020 .

Keating S, "Kisah Singapura dengan program perumahan umum yang dianggap paling sukses di dunia" (BBC News Indonesia, 2019) <https:/www.bbc.com/ indonesia/vert-cap-46755795> diakses 29 Oktober 2020.

Kencana MRB, "PUPR: Program Satu Juta Rumah Lampaui Target” (Liputan6. com) <https://www.liputan6.com/bisnis/read/4089849/pupr-program-satujuta-rumah-lampaui-target> diakses 27 Oktober 2020.

Sandi F, "Waduh! Ternyata Selama Ini Subsidi Rumah Banyak Salah Sasaran" (CNBC Indonesia, 2020) <https://www.cnbcindonesia.com/news/202007231844214-175003/waduh-ternyata-selama-ini-subsidi-rumah-banyak-salah-sasaran> diakses 26 Oktober 2020.

Washarti R, "Satu juta rumah untuk rakyat Indonesia" (BBC News Indonesia, 2015) $<$ https://www.bbc.com/indonesia/majalah/2015/04/150426_bisnis_sejuta_ rumah $>$ diakses 25 Oktober 2020 .

Wibisono N, "Dari Kampung Menuju Rusun dan Apartemen" (Tirto.id, 2017) $<$ https://tirto.id/dari-kampung-menuju-rusun-dan-apartemen-cj3o $>$ diakses 29 Oktober 2020. 


\section{Perundang-undangan}

Constitution Of The Republic Of Singapore.

Keputusan Menteri Pekerjaan Umum dan Perumahan Rakyat Nomor 242/ $\mathrm{KPTS} / \mathrm{M} / 2020$.

Konvenan Internasional tentang Hak Ekonomi, Sosial dan Budaya.

Peraturan Pemerintah Nomor 14 Tahun 2016 tentang Penyelenggaraan Permukiman dan Kawasan Permukiman.

The Acquition Land Act of Singapore.

Undang-Undang Dasar Negara Republik Indonesia Tahun 1945.

Undang-Undang Nomor 39 Tahun 1999 tentang Hak Asasi Manusia.

Undang-Undang Nomor 1 Tahun 2011 tentang Perumahan dan Kawasan Permukiman 
Brillian Aditya: Pemenuhan Hak Masyarakat...

--halaman ini sengaja dibiarkan kosong-- 